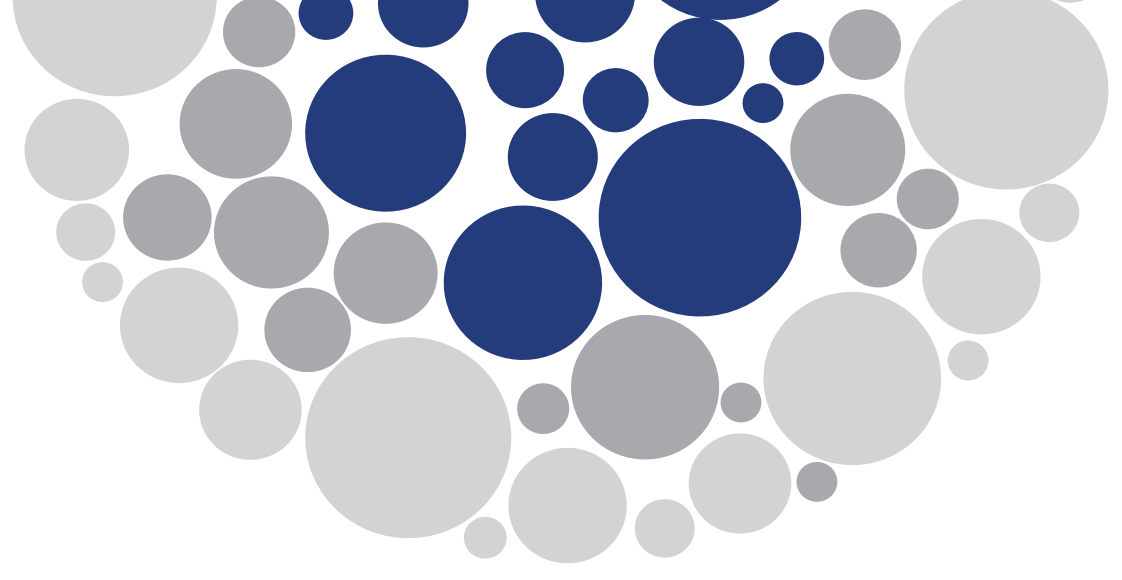

\title{
Quadro de uma Ciência Emergente
}

Já é hoje vasta a literatura geográfica de origem recente da lavra de uma gama de autores que se ramificam pelos departamentos de graduação, programas de pós-graduação e núcleos de pesquisa, ensejando uma bibliografia invejável no panorama nacional e internacional da geografia como ciência engajada e de senso crítico. É o caso dos professores e pesquisadores da unidade de Campos de Goytacazes da UFF - universidade do privilégio de distintos cursos de graduação e pós-graduação e geografia dos diferentes lugares (Campos, Angra dos Reis e Niterói) do estado do Rio -, seu curso de graduação e pós-graduação e o destaque dos trabalhos de participação em eventos da geografia brasileira, artigos e livros que deles fazem uma fértil e influente fonte de referência entre nós.

Bem na linha da renovação dos anos 1970, sua vinculação a uma teoria mais consistente e a uma tradição inarredável de base empírica, reúnem esses colegas neste livro a riqueza dos temas e visões críticas que desde então tornaram a geografia brasileira conhecida e cortejada em todos os cantos, expressando o casamento bem feito das reflexões discursivas das salas de aula e conferições do trabalho de campo, que o leitor pode ver em cada texto. Do trabalho precarizado às denúncias dos ataques ao meio ambiente, aqui desfilam o problema da concentração fundiária rural e urbana, os sujeitos do espaço, os conflitos de territorialidades, o crescimento das lutas identitárias, a defesa do direito à terra, à cidade, ao trabalho digno e remunerado, que marcam o compromisso da geografia com a sociedade real e mais ampla, em um país de monopólios e distâncias gritantes de desigualdade social e distribuição da renda. Um país onde a riqueza produzida por todos cai, no entanto, nas mãos de uma minoria concentracionista e arbitrária.

Textos que mostram a qualidade e a maturidade a que, acadêmica e cientificamente, chegamos nesta quadra de século, sem abrir mão da independência e consciência crítica face um mecanismo e agências de Estado cada vez mais verticalizados e voltados para a sobrecarga estratégica que afasta a intelligentsia e a universidade das tarefas e do cotidiano a que as chamam os momentos-chave de nossa história, como o que vivemos agora. 
Pois qual poderia ser a função de uma intelectualidade acadêmica que não seja a que os geógrafos e a geografia no longo deste novo tempo têm abraçado desde quando, exprimindo o tempo da retomada da vida democrática do Brasil nos idos dos anos $1970 \mathrm{e}$ 1980, declararam sua opção por uma sociedade socialmente mais igual, economicamente mais justa e ambientalmente mais recíproca? Qual é a linha de compromisso que não a de andar por este país - como na música de Gonzaguinha - para ver e fazer ver que neste país - um Haiti que cada vez mais é aqui, do dizer de Caetano - tudo dá, mas nada é dado, tudo é produzido, mas não nasce, desde quando os verdadeiros moradores foram escorraçados e massacrados como se invasores fossem, para quem o produz, mas sim para os que, às custas deles, tudo usufruem, sem produzir um só níquel. Como diziam os antigos. Qual é a tarefa senão esta, de, na competência e seriedade do trabalho, trazer aos textos este país que merecia uma sorte diferente, absolutamente diferente, da que nós temos. E à qual só chegaremos por meios como este, de produzir e dar a público o conhecimento que ele espera de uma universidade verdadeira.

Textos de uma coletânea que engrandece e enriquece a bibliografia geográfica do país, em um dos seus momentos mais necessários. À leitura, pois. 